\title{
From volunteer work to informal care by stealth: a 'new voluntarism' in social democratic health and welfare services for older adults
}

\author{
Gudmund Ågotnes ${ }^{1 *}$ (D), Jill-Marit Moholt ${ }^{2}$ (D) and Bodil H. Blix ${ }^{3}$ (D) \\ ${ }^{1}$ Department of Welfare and Participation and Centre for Care Research - West, Western Norway \\ University of Applied Sciences, Bergen, Norway, ${ }^{2}$ Centre for Care Research - North, Department of Health \\ and Care Sciences, Faculty of Health Sciences, UiT The Arctic University of Norway, Tromsø, Norway and \\ ${ }^{3}$ Department of Health and Care Sciences, Faculty of Health Sciences, UiT The Arctic University of \\ Norway, Tromsø, Norway \\ ${ }^{\star}$ Corresponding author. Email: gago@hvl.no
}

(Accepted 24 September 2021)

\begin{abstract}
In the context of current and expected demographic changes, the issues of which services the welfare state should offer and, ultimately, the very function of the welfare state are currently debated in Norway. The political discourse on health and care services for older adults has morphed into an accepted reality in which the system must be altered, prompting policy makers and stakeholders to find new and novel solutions to problems associated with population ageing. In this paper, we discuss one such proposed solution: the transformation of health and care services for the older adult population through the increased involvement of volunteers. We ask how volunteer efforts are articulated and delineated through official accounts and discuss the implications of such an articulation and delineation. We seek answers to these questions through a critical discourse analysis of recent governmental white papers. We investigate, in other words, volunteer efforts as a political instrument. We argue that the official representation of how efforts in health and care services should be re-aligned take the form of a distinct discourse of 'voluntarism'. Within this 'voluntarism', volunteer efforts have been altered from a third sector comprising charity and non-profit organisations that contribute within or as a supplement to the largely public-run welfare system to a limitless and extensive concept that is blurring the boundaries to informal care.
\end{abstract}

Keywords: volunteer; ageing; informal care; family care; discourse analysis

\section{Introduction}

From a global perspective, people are living longer, and the proportion of older people is increasing. The shift in the distribution of the population towards older ages challenges the sustainability of health and care systems worldwide (World

(C) The Author(s), 2021. Published by Cambridge University Press. This is an Open Access article, distributed under the terms of the Creative Commons Attribution licence (http://creativecommons.org/licenses/by/4.0/), which permits unrestricted re-use, distribution and reproduction, provided the original article is properly cited. 
Health Organization, 2015), leading to reforms for the sustainability of welfare systems (Spasova et al., 2018; Zigante, 2018) accompanied by debates on the division of responsibility between the public and private spheres.

Following other European countries, austerity measures are also affecting the Norwegian welfare state, perhaps primarily in a shift from residential to home care (Spasova et al., 2018). While this issue has not yet taken the form of severe downscaling of (mostly public) welfare services, current debates involve which services the welfare state should offer and, ultimately, the welfare state's very function. Particularly for services directed at the older adult population, arguments for change are being voiced. A 'sustainability discourse' (Blix and Hamran, 2018) has increasingly dominated public narratives about services for the older adult population: the increase in the older adult population relative to the increase in the workforce is too high for the welfare system to function in its current form. For instance, it is proposed that the current welfare system will require a 75 per cent increase in the workforce by 2035 (Ministry of Health and Care Services, 2018: 45). Given the expected demographic developments, this increase will be difficult to achieve.

The political discourse on welfare services in the context of expected demographic changes has morphed into an accepted reality in which the system must be altered (Blix and Hamran, 2018). This has prompted policy makers and stakeholders to find new and novel solutions to current and future problems. In their current form, these proposed solutions activate familiar concepts in an international context, such as 'healthy ageing', 'active ageing', 'age-friendly society' and 'ageing in place', and a stronger reliance on voluntary efforts (World Health Organization, 2015).

In this study, we discuss one proposed solution, the transformation of health and care services for the older adult population through the increased involvement of volunteers. We ask how volunteer efforts are articulated and delineated in official accounts and discuss their implications through an analysis of recent Norwegian governmental white papers. In other words, we present a premise - the political aim of an increase in the extent of volunteer contributions connected to the increasing number of older citizens - and two main areas of exploration - the intended form of such a shift and what its implications might be. We argue that this proposed solution has taken the form of a distinct discourse of 'voluntarism', that is, a public interpretation and articulation of a phenomenon containing both an inherent meaning and potential practical implications. Within this 'voluntarism', volunteer efforts are altered from a third sector comprising charity and non-profit organisations that contribute within or as a supplement to the largely public welfare system to a limitless and extensive concept, blurring the boundaries to informal care.

As there is a dearth of knowledge about the scope of volunteer efforts in the welfare sector, particularly regarding care for older adults (Skinner et al., 2020), our study will inform important areas of research and policy developments.

\section{Background: characteristics and developments of the Norwegian welfare state}

In an international context, measures of austerity have influenced or are threatening to influence welfare services in general (Norman and Uba, 2015; Stuckler et al., 
2017) and care for the ageing population in particular (Deusdad et al., 2016; Gori, 2019), prompting policy initiatives directed at substituting or complementing exciting models (Pavolini and Ranci, 2008). Public services are being downsized, leading to an increased reliance on alternative provisions of labour, such as non-profit or volunteer organisations (Lorentzen and Tingvold, 2018), or privately purchased services (Daly and Armstrong, 2016). Additionally, contributions from 'significant others' (family members, friends or neighbours) are affected by these changes, for instance, as an implication of changed market mechanisms (Ulmanen and Szebehely, 2015) or through financial governmental incentives (Grootegoed et al., 2015).

In the Nordic context, debates on the relationship between and synergy of the public, corporate and informal sectors in service provision, or the 'welfare mix', have intensified recently (Arbeidsgiverforeningen Spekter and NHO Service og Handel, 2019), even though they have been present in public discourse since the 1970s (Loga, 2018). Nevertheless, the Nordic welfare model is generally characterised by high overall public expenditure and a high proportion of public service provision (Christensen and Wærness, 2018). The model is further characterised by universalism, in which access to services should be given to all citizens, while the form of services and benefits follows a principle of equity in which those most in need should receive more (Dahl et al., 2014). While processes of de-universalism (including for-profit provision of care service, services paid out-of-pocket and increased family care) are threatening the Nordic model, Norway has so far been less affected than Finland and Sweden (Szebehely and Meagher, 2018). The thresholds for accessing public care were raised due to recession in Finland and Sweden in the early 1990s (Szebehely and Meagher, 2018), a recession that impacted Norway to a lesser extent. However, Norway followed on a similar track a decade later due to competition for limited care resources (Gautun and Grødem, 2015).

Care for the older adult population is considered a core responsibility of the Nordic welfare states while being organised somewhat differently in each country. In Norway, public expenditures in this sector are high (Christensen and Wærness, 2018) in terms of both overall and relative amounts. The level of staffing is also considered high when considering both the overall level (staff/patient ratio) and the degree of formal competency (registered nurse/patient ratio, for instance) (Harrington et al., 2012). Older adult care, primarily in the form of nursing homes, assisted living and home care services, is predominantly a municipal responsibility (Ågotnes, 2017; Christensen and Wærness, 2018). Municipal health and care services are an essential employer in Norway, comprising almost 145,000 full-time equivalents in 2019 (Statistics Norway, 2020a), a majority of whom are women. A high degree of public service provision coincides with a high proportion of public, as opposed to familial, responsibility for the care of the ageing population (Otnes, 2012: 57), comprising what has been described as a Scandinavian model of de-familisation (Daatland, 2012: 21). This model is not simply a political project but is also widely regarded by the public as a preference (Daatland and Veenstra, 2012a).

Similar to other comparable countries, Norwegian health-care authorities have conceptualised 'ageing in place' as a goal for older adults (Ministry of Health and Care Services, 2015a, 2015b). The relative coverage of nursing home beds for the oldest population has decreased, whereas various forms of assisted living 
arrangements and home-based services have increased (Spasova et al., 2018). These developments can be seen in relation to a discursive shift in public debates and in the political landscape about a need for change regarding how society views and responds to its older citizens. Such a 'sustainability discourse' (Blix and Hamran, 2018) rests on the assumption that the number of future care recipients does not match the number of potential care providers, thus representing a financial burden that is too high given our current system of health and care services. Something must change; something must be done differently, better or more efficiently through a reorganisation of service provision, such as through measures of assistive technology, innovative new solutions or increased privatisation and/or commercialisation of service provision (Ministry of Health and Care Services, 2018; Arbeidsgiverforeningen Spekter and NHO Service og Handel, 2019). An important element in the proposed developments, as seen internationally, is a proposed move towards volunteering, that is, the expectation that volunteer efforts should replace, supplement or add to public efforts (Christensen et al., 2020). The 'sustainability discourse' serves, in other words, as a premise for increased volunteer efforts, which is interestingly more pronounced in governmental papers compared to interests and opinions voiced by the population (Daatland and Veenstra, 2012a; Christensen et al., 2020).

Despite this call for the increased involvement of volunteers, the general level of organised volunteer work has been and remains comparatively high in Norway, increasing rapidly from the end of the Second World War until the 1990s while flattening in the period after (Wollebæk and Selle, 2002). Nevertheless, volunteer efforts have remained strong in recent times (Finstad, 2018) while changing towards smaller, decentralised and more specialised organisations (Blix and Hamran, 2018). Compared to other European countries, citizens in Nordic countries report significantly higher levels of involvement in organised volunteer efforts (Eurostat, 2016). While the average for European countries is 18 per cent, the averages for Norway, Denmark and Sweden are 35, 28 and 25 per cent, respectively. However, care for the older adult population has largely remained within the realm of the public sphere, while volunteer organisations and initiatives have directed their attention elsewhere, primarily at leisure activities (sports and recreation) for the younger population (Finstad, 2018) and towards 'culture' (Statistics Norway, $2020 b$ ). In one recent Norwegian study, 4.4 per cent of respondents reported contributing to volunteer work in long-term care services, while 20 per cent reported providing regular informal care 'to someone with special needs', which was performed largely by an ageing population (Skinner et al., 2020). The potential for increased volunteer efforts in care services is therefore stressed (Lorentzen and Skinner, 2018; Skinner et al., 2020).

Finally, the way that public care, volunteer efforts and informal/family care are categorised, including the boundaries between them, is complex and might even be contested, in part because 'care' and 'care work' are challenging to define (Ervik and Linden, 2017). The volunteer sector is a complex landscape consisting of (a) idealistic institutions with paid employees, (b) organisations performing unpaid volunteer work outside institutional care, and (c) individuals contributing to volunteer work (Ervik and Linden, 2017: 13). The latter two can be labelled 'volunteer efforts' directed, for instance, at the older adult population, in contrast not only to the 
former but also to unpaid work by family members, often labelled 'informal' or 'family care' (Berge et al., 2014; Zigante, 2018). Elsewhere, the help and support provided by both families and volunteers have been characterised as informal care' (Førland, 2015), signifying a complex relationship between not only the different concepts and categories but also, perhaps, practices. In this article, we address 'volunteer efforts' understood as unpaid work directed at non-family members while arguing that the emerging discourse on volunteer efforts might imply a broadening of such an understanding.

\section{Methodology and analysis}

This article is based on a discourse analysis (Bacchi, 2009) of four Norwegian government white papers addressing the volunteer sector and/or care and welfare services for the older adult population. All documents are Reports to the Storting (Parliament), Stortingsmeldinger, that is, documents published by the government or specific ministries with the aim of presenting matters to the Parliament that do not require decisions. Such white papers are the government's report to the Parliament on the work conducted in a particular field, and they often form the basis of a draft resolution or bill at a later stage.

The first two documents were included because they explicitly address the volunteer sector while being published 11 years apart (Table 1). Hence, these two documents provided the opportunity to study potential changes in the conceptualisation of the volunteer sector over an extended time period. The latter two documents were included because they address older adults, care and public health issues, including volunteer efforts. Hence, these two documents provided the opportunity to study the conceptualisation of the volunteer sector with reference to the particular context of health-care services and older adult care. By including these two categories of documents, we aimed to investigate an overarching understanding and articulation of volunteer work as well as its more concise interpretation and application within the specific field of health and care services. As such, the included documents represent a strategic yet not exhaustive sample of relevant Norwegian government white papers. By including these documents, we aim to capture developments over time while analysing volunteer efforts from different vantage points. The total data material consisted of 775 pages.

We consider white papers both products of discursively based understandings of aspects of the social world and active producers of understandings and practices. Consequently, we believe that a discourse analysis of white papers can provide insight into the predominant understanding of and policies aimed at a particular phenomenon in a specific society at a specific point in time. In the Norwegian context, governmental white papers have been described as a central political tool (Christensen and Fluge, 2016) that is particularly effective in determining future policy and service directions (Jacobsen, 2015).

Following Bacchi (2009), we analysed the documents with the aim of identifying 'what the problem is represented to be (WPR)'. From the starting point of the proposed solutions, we demonstrate how the 'problem' is represented as well as the underlying ideological and political assumptions (Bacchi, 2009; Christensen and Fluge, 2016; Jenhaug, 2018). According to Bacchi and Bonham (2014), the focus 
Table 1. Government white papers

\begin{tabular}{|c|c|c|}
\hline Document & Responsible ministry & $\begin{array}{c}\text { Year } \\
\text { published }\end{array}$ \\
\hline $\begin{array}{l}\text { Meld. St. } 39 \text { (2006-2007) Frivillighet for alle } \\
\text { [Voluntarism for All], } 291 \text { pp. }\end{array}$ & $\begin{array}{l}\text { Ministry of Church and } \\
\text { Culture - Church Affairs }\end{array}$ & 2007 \\
\hline $\begin{array}{l}\text { Meld St. } 10 \text { (2018-2019) Frivilligheita-sterk, } \\
\text { sjølvstendig, mangfaldig-Den statlege } \\
\text { frivilligheitspolitikken [Voluntarism - Strong, } \\
\text { Independent, Diverse - The Governmental Voluntary } \\
\text { Policy], } 96 \text { pp. }\end{array}$ & Ministry of Culture & 2018 \\
\hline $\begin{array}{l}\text { Meld. St. } 15 \text { (2017-2018) Leve hele livet - En } \\
\text { kvalitetsreform for eldre [A Full Life - All Your Life - A } \\
\text { Quality Reform for Older Persons], } 184 \text { pp. }\end{array}$ & $\begin{array}{l}\text { Ministry of Health and } \\
\text { Care Services }\end{array}$ & 2018 \\
\hline $\begin{array}{l}\text { Meld. St. } 19 \text { (2018-2019) Folkehelsemeldinga-Gode } \\
\text { liv i eit trygt samfunn [Public Health Report-Good } \\
\text { Lives in a Safe Society], } 204 \text { pp. }\end{array}$ & $\begin{array}{l}\text { Ministry of Health and } \\
\text { Care Services }\end{array}$ & 2019 \\
\hline
\end{tabular}

of WPR analysis is on the deep-seated ways of thinking that underpin political decisions. The interest is not in 'discovering knowledge' but rather in how forms of knowledge are linked to power and politics.

Bacchi and Goodwin (2016) suggest an approach involving a series of six questions: (a) What is the problem represented to be?; (b) What deep-seated presuppositions or assumptions underlie this representation of the 'problem'?; (c) How has this representation of the 'problem' come about?; (d) What is left unproblematic in this problem representation? (Where are the silences?) Can the 'problem' be conceptualised differently?; (e) What effects are produced by this representation of the 'problem'?; and (f) How and where has this representation of the 'problem' been produced, disseminated and defended? How has it been and/or how can it be disrupted and replaced?

In our analysis, we adapted these questions to our context by slightly altering how they are formulated. Based on these modifications, the following primary and secondary research questions guided our analysis:

- How are volunteer efforts understood and articulated in Norwegian governmental white papers, particularly regarding the care sector/older population? - What deep-seated presuppositions and ideologies underlie this representation?

- How has this representation of the 'problem' come about?

- What is left unproblematic in this problem representation?

- What potential implications can be drawn from this representation of the problem?

Our analysis was a stepwise process between readings of the included texts, guided by the aforementioned questions, and discussions among the authors. An initial and comprehensive review of the included documents was conducted by the first author, producing subjects related to the mentioned questions. These were critically examined by the co-authors, who were familiar with the included documents in 
advance and later re-examined by all authors going back to the original documents. Several subsequent discussions among the authors reduced the potential for bias.

Quotes from the included documents were translated from Norwegian to English by the authors. All translations were translated as literally as possible at the possible expense of a more fluid English language. The authors take responsibility for any misrepresentation in the translated quotes.

\section{Results}

\section{'All aboard' - volunteer efforts by the state}

Here, we present an outline of how volunteer efforts were represented in a Norwegian political context, both as a general concept and in relation to the older adult population, starting with the more descriptive presentation of the sector. Although the Norwegian welfare state is known for its extensive public support system, volunteering, in the form of ideal and/or non-profit charitable organisations, is presented as having a longstanding tradition in Norway. In one white paper, volunteering as a general practice is traced back to the Middle Ages through the Norwegian term dugnad (Ministry of Culture, 2018: 11), a form of collective and practical action towards the common good, for instance, in the context of a neighbourhood or a village. Dugnad is connected to volunteer efforts in the sense that both categories are based on a commonly shared cultural characteristic in which people make an effort to support others based on altruistic intentions.

The organised form of volunteering, meanwhile, is traced back to the early 1800 s, evolving by the mid-1800s and onwards towards providing care, support or relief to those in need (Ministry of Culture, 2018: 12), primarily in the form of religious and labour organisations. These initiatives are presented as predecessors of the current largely publicly funded welfare system (Ministry of Culture, 2018: 150-151). Additionally, long-term care institutions for the older population were originally established by volunteer organisations targeting the poor older population without family support systems while being gradually replaced by nursing homes with a more pronounced universal approach (Ministry of Culture, 2018: 12). Furthermore, the volunteer sector is presented as being in a symbiotic relationship with the public sector, historically paving the road for later public efforts in the care sector while taking a backseat in modern times. Nevertheless, the scope of the third sector is presented as formidable and as thriving in contemporary Norway: over half of the grown population is in some way involved in this sector within its 115,000 organisations, presented as high in an international context.

The volunteer sector is presented as extensive and important in the included documents. Given this significance, how are volunteer efforts understood in a political context? What is and what is not included in the concept, and what is presented as its function and potential? The slogan 'alle skal med', translated to 'all aboard', runs throughout one of the included white papers (Ministry of Church and Culture - Church Affairs, 2007). This slogan captures not only the merits of volunteering in itself but also its links to the universalistic moral philosophy embedded in the Norwegian welfare state: 'But without a strong civic society in which the individuals together contribute to good local communities, we cannot succeed in the efforts to create a society in which all shall be part' (Ministry of 
Church and Culture - Church Affairs, 2007: 19). As such, volunteering is presented as having intrinsic qualities and as an integral part of modern society. In a second white paper on volunteer efforts (Ministry of Culture, 2018), the inherent significance of volunteer efforts is also noted. Volunteer efforts are presented as a positive moral value for society that will increase involvement and lead to democratisation processes: 'Voluntarism are schools of democracy that all should be able to attend' (Ministry of Culture, 2018: 32).

In another recent white paper (Ministry of Health and Care Services, 2019), the underlying merits and qualities of the volunteer sector are reiterated and transferred more explicitly to the context of the older segment of the population. It is argued that the efforts of the volunteer sector are particularly important in combating 'loneliness' and 'isolation' among the older population (Ministry of Health and Care Services, 2019: 43-46). These are areas the public care sector has difficulties reaching, alluding to a symbiosis of the public and voluntary systems. With this, the volunteer sector not only represents an important moral value and an obligation for citizens but also an important societal function that supplements and adds to existing efforts and is an integral part of the welfare state as a whole.

In summary, volunteering is presented in white papers as having an important societal function that is connected to Norwegian culture and tradition, and as a moral virtue. This presentation represents both an interpretation and articulation of a phenomenon in the form of a delineation of volunteer efforts. As expressed in the white papers, volunteer efforts are good in themselves and lead to good things. Despite these commonalities, we have identified a development in the understanding and boundaries of what is included in volunteer efforts in later white papers.

\section{Volunteer efforts version 2}

In the more recent white papers, we see a shift in how the older adult population is considered providers and not simply recipients of volunteer efforts. In one of the included white papers that is explicitly concerned with the demographic changes on the horizon, one of the more specific aims is to double the amount of 'volunteer work' performed by the older adult population by 2030 (Ministry of Health and Care Services, 2018: 12). The older adult population is presented as an unexploited resource with the potential to contribute both in society and in 'their own lives' (Ministry of Health and Care Services, 2018: 59). An increased contribution will result in the dual output of a more active and healthier older adult population and a more robust volunteer sector. 'The new seniors' are also presented as more resourceful than their earlier counterparts (Ministry of Health and Care Services, 2018: 43); they are more mobile, have wider networks and have more financial stability than preceding generations.

An important element in the presentation of volunteer efforts and the older adult population is the narrative of 'continued participation in civic society' in old age (Ministry of Health and Care Services, 2019: 8). This notion is presented in part as a moral project where inclusion of the older adult population in societal life is central but also as a more pragmatic or instrumental incentive; it is cost efficient. The term 'active ageing' is incorporated into this rhetoric: 'The most 
important strategy will be to encourage the future senior population to continue active participation in society' (Ministry of Culture, 2018: 152). An explicit emphasis on 'user involvement' and 'participation' is prevalent (Ministry of Health and Care Services, 2018, 2019), connected to the dual outputs of (a) 'staying active' (and healthy) and (b) 'empowerment'. For instance, it is emphasised that the older adult population should be involved in shaping both policies and practices that affect the older adult population and thus have a say in matters that affect them. In summary, a discourse about the merits of volunteer efforts for the older adult population is prevalent: 'volunteering is good for the volunteer'.

We have also identified a shift in how recent white papers delineate volunteer efforts, from that of organisational work to include a wider array of activities and contributions. In the earliest white paper, volunteering is presented as organisational work, representing a separate and autonomous sector: 'The solution to the great welfare challenges shall be a public responsibility. However, as a consequence of its endeavours, volunteer organisations also solve important tasks in society and contribute to the fulfilment of society's goals. It is important to stress the uniqueness and autonomy of voluntarism' (Ministry of Church and Culture - Church Affairs, 2007: 11). Here, a clear line of demarcation is drawn between the public and the volunteer sector: the latter consists of various organisations with respective target areas (Ministry of Church and Culture - Church Affairs, 2007: 24) and is characterised by being non-profit and membership based.

In the latest white paper addressing the volunteer sector (Ministry of Culture, 2018), the concept of volunteer efforts or volunteering is somewhat expanded. In this document, volunteer efforts are connected to civic society in general (Ministry of Culture, 2018: 7; 15), signifying a shift in seeing volunteer contributions as efforts or activities rather than work: 'The public policy on voluntarism should facilitate active citizenship for the individual. Volunteer participation is the foundation of trust, community and a plurality of activities' (Ministry of Culture, 2018: 16). The high degree of 'social trust' characterising Norwegian and Nordic societies is emphasised. This characteristic is presented as a prerequisite for the high number of volunteer organisations and the extent of other volunteer initiatives. Notably, both volunteer organisations and other forms of volunteer initiatives are referred to in singular form as 'voluntarism' ('Frivilligheita'). As such, volunteer efforts are portrayed as a vital component of societal life in general and as a component of good life: 'A good society is built from the bottom up, and it is the government's aim to spread power by giving the individual, families and local communities the means to govern' (Ministry of Culture, 2018: 7). With this, a 'voluntarism' is constructed, containing not only the more or less concrete efforts by an identified provider of services operating in a social space within a given timeframe but also a part of societal life in a more general sense. Furthermore, this effort is presented as an important counterforce to both public and commercial alternatives, for instance, by pointing out its role in the empowerment of marginalised groups:

The voluntarism is therefore important as a democratic infrastructure where those who participate get experience in being an actor in a democracy. Organisations that promote civic rights are a prerequisite for civic society. The civic society 
creates discussions that gives legitimacy to laws and political decisions (Ministry of Culture, 2018: 15).

A broadening of what volunteer efforts contain is also evident in the later white paper's (Ministry of Health and Care Services, 2019) emphasis on 'co-operation'. 'Co-operation' is emphasised in descriptions of how sectors could and should overlap, that is, through increased collaboration between the volunteer sector and the private and public sectors (Ministry of Health and Care Services, 2019: 8, 76, 148, 153-154): 'The government will protect the existing voluntarism, mobilise new groups of volunteers and extract the potential of development that lies in co-operation with private businesses' (Ministry of Health and Care Services, 2019: 153). Co-operation, as we read it, becomes both a premise for and a result of increased volunteer efforts.

Parallel with the broadening of 'voluntarism', we have identified an increased emphasis on informal care provided by family care-givers in the two recent white papers (Ministry of Health and Care Services, 2018, 2019). Family care is described as 'almost ... the same size as municipal care' (Ministry of Health and Care Services, 2018: 46) but also as fragile, given more individualistic preferences and ideals among future potential family care-givers. Because of this fragility, the state plays a role in facilitating the future growth of this informal sector and combating its potential decline. We also see an extension of the concept 'family care' to involve persons other than the closest family/next of kin: 'Family care-givers can be a partner/spouse, children and grandchildren, friends, colleagues and significant others' (Ministry of Health and Care Services, 2018: 46). The sustainability discourse is also highly present in the rhetoric on informal care: 'Family care-givers are an invaluable resource, both for the persons they care for and for the health and care services. It is also a renewable resource if attended to' (Ministry of Health and Care Services, 2018: 46).

Interestingly, in relation to what we have described as a broadening of both volunteer efforts and informal care, the role of the public sector is also transformed. In a broader volunteer effort, the role of the public sector has changed to a more active role in the recruitment and training of volunteer workers within the care sector (Ministry of Health and Care Services, 2018: 83). Similarly, regarding informal care, the public sector should support those who contribute: 'It will obviously be wise to support and take good care of next of kin who take on care responsibilities and to facilitate co-operation with local communities and the volunteer sector' (Ministry of Health and Care Services, 2018: 45).

In conclusion, we see both a shift towards an expressed need for more volunteer efforts, in part by the older population themselves, and a conceptual broadening of both volunteer efforts and family care. This shift is presented partly explicitly, especially with respect to increased involvement by the older adult population themselves, and partly implicitly, through an increased emphasis on positively laden terms such as 'participation', 'user involvement' and 'co-operation'. Through such a broadening of terms, the boundaries of volunteer efforts become blurred, as we shall return to, towards informal care. This blurring of boundaries is perhaps best illustrated by the description of the older adult population as having multiple roles within and between the different categories: 
Many older adults are resourceful, have good health and will, eventually, have better education. That provides a good foundation to be able to contribute significantly in society and as workers, as grandparents and as care providers for those closest to them, and as participants in volunteer work, for instance through Volunteer Centrals and day centres (Ministry of Health and Care Services, 2018: 83).

\section{Discussion}

\section{Representation of the problem and underlying presuppositions}

Returning to Bacchi's sequence of questions, we find that 'the problem'- the unsustainability of the current state of affairs - is presented as given and largely left unproblematised. A potential solution to 'the problem' is explicitly stated: increased volunteer efforts. This problem representation and its potential solution leave some matters unattended or silenced, to which we will return. The problem presentation and the presented solution also rest on a set of assumptions to which we now direct our attention.

The representation and articulation of volunteer efforts in all the included white papers seem to follow an argumentation in which involvement in civic life is somehow indicative of how well-functioning a society is, as proposed by Putnam (2000). Involvement in civic society, as measured through 'social capital', is a benchmark for modern society and is, as such, unequivocally positive: it is a representation of an apex (Ministry of Church and Culture-Church Affairs, 2007: 62). Volunteer effort is understood as an end in itself; it has its own inherent qualities. Volunteer efforts, in this version, also become a means to an end: it is related to more efficient and well-functioning political processes, for instance. Thus, volunteer efforts are both a solution to a conceived problem and an instrument indicating the seriousness of the problem.

Despite this overarching commonality, the official articulation of volunteer efforts has changed over time in two related ways. We see an increased inclusion of the older adult population as providers of volunteer efforts paralleled with a general broadening of what volunteer efforts are supposed to contain. The older adult population should contribute more, for the sake of society and for their own sake. Again, we find an articulation of a self-strengthening duality: the older adult population has a right and a duty to contribute to the greater good while simultaneously improving their own situation. The former part of this argument is apparently indisputable: older adults should have the opportunity to be actively involved in society. This right to be involved coincides with Christensen and Fluge's (2016) remarks about a discursive shift towards co-production and user involvement, in which responsibilities shift from the state to the older adult population.

The latter part of the argument, meanwhile, signifies the moral fundament of a revamped version of 'volunteer efforts' and speaks to the ideological underpinnings of the problem representation: the citizen has an obligation to contribute to a collective endeavour. Moreover, inherent in the argument is the presentation of volunteer efforts as an organisational alternative to the existing welfare model that is under pressure. Individuals, families, social networks and local communities are expected to undertake more responsibilities, which is justified by fellow citizenship 
and solidarity between generations. To ensure financial sustainability within public health and care services, citizens should not perceive themselves as consumers of welfare services but rather contribute to reducing the requirement for services. This shift follows Blix and Hamran's (2018) argument about a change in public discourse from a 'prevention discourse', in which volunteer activities are represented as benefiting older adult volunteers, to a 'sustainability discourse', in which volunteer efforts are represented as a necessity to meet future challenges in welfare services.

In sum, volunteer efforts have moved from representing an autonomous sector to being incorporated into the public welfare system, illustrated, for instance, by the idea that the public sector should facilitate, guide and recruit volunteers to a larger degree. This shift is connected not only to new lines of demarcation between the public and the civic sectors but also to a lack of clarity about what volunteer efforts are supposed to contain, making the lines of demarcation less visible. Voluntary efforts no longer belong solely to the recognisable and traditional third sector and the organisations under its umbrella but are also considered a crucial contribution to the less tangible 'all the good forces'. This porosity is evident in the use of different terms as synonyms or in connection to volunteering as well as in a change in the use of terms, from organisations to work (Ministry of Culture, 2018: 7), from sector to efforts and from volunteer care to the volunteer and primarily family-based care (Ministry of Health and Care Services, 2018: 46), often without a clear explanation or exemplification of what is being discussed.

\section{'Voluntarism' version 3? Silences and potential implications}

We argue that the broadening of what is understood by 'volunteer efforts', in combination with a porous and often unresolved relation to other related terms and phenomena, represents a shift in public discourse towards a new 'voluntarism'. In the white papers included in this study, the relationship between informal care and the volunteer sector is left unresolved, in part through associations with positively laden terms such as 'co-operation' and 'user involvement'. These associations, in combination with an entanglement of terms and categories, make it difficult to ascertain what exactly is being addressed and when. As for the case of home care services in Finland, we argue that such a shift is proposed without 'any real policy debate or major modification of Legislation' (Kröger and Leinonen, 2012: 319), thus representing a transformation in stealth based on the assumption that change is both imminent and necessary. This unresolved and limitless 'voluntarism' may include, we further argue, what has been considered outside, or at the fringes of, the realm of a traditional delineation of the volunteer sector, specifically: forms of informal care. Informal care is potentially reintroduced under the veil of a new 'voluntarism'.

Interestingly, informal or family care represents a grey area in statistics and is difficult to measure (Daatland and Veenstra, 2012b), contributing to an invisibility of such efforts on a more empirical level. This was also noted by Zigante (2018: 10), who stated, 'The confusion regarding the conceptualization of informal care leads to issues with it comes to measuring the prevalence of informal care'. Lack of knowledge about the scope of informal care coupled with the fact that these are documents concerned with future policy changes makes questions of the 
implications of such an inclusion difficult to pinpoint. We can, however, draw on some sources to outline potential implications of what we see as a dissolution of the boundaries between informal care and volunteer efforts.

In an international context, what has been described as a process of 'familisation' is not new. Hulcko et al. (2017: 194) argued that because of recent austerity measures, an overreliance on unpaid family care is increasingly occurring and has morphed into an accepted reality, in which civic contributions in long-term care are considered a new 'normal' (Grootegoed et al., 2015: 111). As a result of the downscaling of services, particularly for the older adult population, families are left as the only option. Similarly, Ulmanen and Szebehely (2015: 86) demonstrated that informal and unpaid care work performed by family members in Sweden has increased since 2000, while private and commercial service provision did not increase despite policy intentions to offer choice between public or private/commercial providers. The authors described increased responsibilities for adult children and other non-cohabiting family or friends as a result. These developments echo those of the Netherlands, where an increase in informal care inequitably affects the population (Van den Broek et al., 2019): groups with lower educational levels and women are left with a larger burden of responsibility (Grootegoed et al., 2015: 126). The consequences of these policy initiatives, intended or not, can therefore be described as a process of re-familisation (Saraceno, 2010; Szebehely and Meagher, 2018), in which the burden of responsibility is shifted towards women. Somewhat contrarily, Pavolini and Ranci (2008: 257) argue that an increase in cash benefit policies in several European countries 'constitute strong institutional recognition of the care work performed by women, previously considered as an implicit and "natural" duty' (Ranci and Pavolini, 2015: 281). They argue that recent policy reforms constitute a reformation rather than a reduction of welfare regimes, leading to a 'recasting of the relationship between State and the family' (Ranci and Pavolini, 2015: 281). This 'recasting' is, meanwhile, conducted somewhat differently between countries adopting a service-led model and those adopting an informal care-led model (Pavolini and Ranci, 2008: 257-258). The development seen in Sweden and the Netherlands is perhaps symptomatic for such a 'recasting' in a service-led model to which Norway belongs.

The question remains whether these patterns of development will occur in Norway. The scope of informal care remains comparatively low in Norway but is predominantly performed by women (Skinner et al., 2020). Interestingly, women are particularly overrepresented in help and support 'outside one's own household' (Skinner et al., 2020); equivalent to, we believe, 'adult children and other noncohabiting family'. This suggests that if similar patterns occur in Norway, supported by the mentioned discursive shift, family, and women/daughters in particular, will carry the major burden.

\section{Conclusion}

A hidden or not explicitly addressed impact of the discussed discursive change is not only an intended shift of responsibilities from the public to the volunteer sector, it might also include a stronger reliance on families. A stronger reliance on informal and family care is, as seen elsewhere (see Kröger and Leinonen, 2012), a potential 
implication of a blending of the responsibilities between public services and the volunteer sector, leaving informal and family care to 'fill the void'. This mechanism may be particularly relevant for robust, universal welfare models, as opposed to residual models (Ranci and Pavolini, 2015), contrary to the very objective of the universal welfare state (Szebehely and Meagher, 2018).

As shown by examples from Sweden and Finland, the withdrawal of the public sector leads, intentionally or not and explicitly or not, to increased reliance on informal and family care. We argue that this general shift or trend rests on an ideology of 'familism', described as

an ideology that identifies the (nuclear) family as the most appropriate and valued form of care, regardless of the realities, needs and/or desires of individual family members or the functionality of the family unit. Familism is characterised by hetero-patriarchy in that women are assumed to be the natural care providers (Hulcko et al., 2017: 195).

Through an ideology of familism, in which care provided by those closest to those in need is considered the ideal, the withdrawal of the state is legitimised through a gender-neutral narrative, remaining gendered in consequence (Grootegoed et al., 2015).

In our context, a less explicit form of familism can be identified in the appraisal of volunteer efforts and increased involvement in civic society, legitimising a shift in responsibility from public providers to 'all the good forces'. An unresolved issue in governmental documents is that 'good forces' may include not only volunteer organisations but also informal and family care. As such, we may be witnessing a shift in responsibilities not only from the state to the older adult population themselves (Christensen and Fluge, 2016) but also from the state to significant others. Veiled in a 'discourse of responsibility' (Jenhaug, 2017), the implications of such a shift in responsibility are not accounted for or made transparent.

Acknowledgements. An earlier version of this paper was presented at the Centre for Care Research West, Western Norway University of Applied Sciences, and at the research group Praxeology at the University of Bergen. We are grateful for constructive feedback following these presentations. We also thank Professor Pat Armstrong, York University, and the research team on the project 'Changing Places: Un-paid Work in Public Places' for guidance and inspiration.

Author contributions.

All authors have made substantial contributions to the design, analysis, writing and revision of this article.

Conflict of interest. The authors confirm that they have no affiliations with or involvement in any entity with any financial interest in the subject matter discussed in this article.

\section{References}

Ågotnes G (2017) The Institutional Practice: On Nursing Homes and Hospitalizations. Cappelen Damm Akademisk Open Access. Available at https://press.nordicopenaccess.no/index.php/noasp/catalog/book/12.

Arbeidsgiverforeningen Spekter and NHO Service og Handel (2019) Morgendagens Omsorgsutfordinger-Behov for en Velferdsmiks. Utvalgsrapport [Tomorrow's Care Challenges-The Need for a Welfare Mix. Report]. Available at https://www.nhosh.no/contentassets/ea9afed9bb81480ca057dcfbb02221ce/omsorgsutvalget_utvalgsrapport_web.pdf. 
Bacchi CL (2009) Analysing Policy: What's the Problem Represented to Be? Frenchs Forest, Australia: Pearson Australia.

Bacchi C and Bonham J (2014) Reclaiming discursive practices as an analytic focus: political implications. Foucault Studies 17, 173-192.

Bacchi C and Goodwin S (2016) Poststructural Policy Analysis: A Guide to Practice. New York, NY: Palgrave Macmillan.

Berge T, Øien H and Jakosson LN (2014) Formell og Uformell Omsorg: Samspillet Mellom Familien og Velferdsstaten [Formal and Informal Care: The Interplay Between the Family and the Welfare State] (NOVA notat 3/14). Oslo: Velferdsforskningsinstituttet NOVA.

Blix BH and Hamran T (2018) 'When the saints go marching in': constructions of senior volunteering in Norwegian government white papers, and in Norwegian senior volunteers' and health-care professionals' stories. Ageing \& Society 38, 1399-1428.

Christensen K and Fluge S (2016) Brukermedvirkning i norsk eldreomsorgspolitikk - Om utviklingen av retorikken om individuelt ansvar [User participation in Norwegian elderly care policy - the development of rhetoric about individual responsibility]. Tidsskrift for Velferdsforskning 19, 261-277.

Christensen K and Wærness K (2018) Long-term care services in Norway. In Christensen K and Pilling D (eds), The Routledge Handbook of Social Care Work Around the World. Abingdon, UK: Routledge, pp. $15-28$

Christensen DG, Ervik R and Lindèn TS (2020) Befolkningens holdninger til økt bruk av ubetalte frivillige i eldreomsorgen: Resultater fra et surveyeksperiment [The population's attitudes towards increasing the use of unpaid volunteers in elderly care: results from a survey experiment]. Tidsskrift for Omsorgsforskning 6, 1-16.

Daatland SO (2012) Aldringen av befolkningen og eldreomsorgen - hensikten og problemstillingene [The ageing of population and older adult care - purpose and problems to be addressed]. In Daatland SO and Veenstra M (eds), Bærekraftig Omsorg. Familien, Velferdsstaten og Aldringen av Befolkningen (NOVA rapport 2/12). Oslo: NOVA, pp. 17-24. Available at https:/oda.oslomet.no/oda-xmlui/bitstream/handle/20.500.12199/5054/5390_1.pdf?sequence=1\&isAllowed $=y$.

Daatland SO and Veenstra M (2012a) Fra praksis til idealer: Hvem bør ha ansvar for hva? [From practice to ideals: who should be responsible for what?]. In Daatland SO and Veenstra M (eds), Barekraftig Omsorg. Familien, Velferdsstaten og Aldringen av Befolkningen (NOVA rapport 2/12). Oslo: NOVA, pp. 157-172. Available at https://oda.oslomet.no/oda-xmlui/bitstream/handle/20.500.12199/5054/ 5390_1.pdf?sequence=18isAllowed=y.

Daatland SO and Veenstra M (2012b) Generasjoner, hjelp og hjelpere [Generations, help and helpers]. In Daatland SO and Veenstra M (eds), Barekraftig Omsorg. Familien, Velferdsstaten og Aldringen av Befolkningen (NOVA rapport 2/12). Oslo: NOVA, pp. 137-146. Available at https://oda.oslomet.no/ oda-xmlui/bitstream/handle/20.500.12199/5054/5390_1.pdf?sequence $=1$ \&isAllowed=y.

Dahl E, Bergli H and van der Wel K (2014) Sosial Ulikhet i Helse: En Norsk Kunnskapsoversikt [Social Inequity in Health: A Nordic Review]. Oslo: Høgskolen i Oslo og Akershus.

Daly T and Armstrong P (2016) Liminal and invisible long-term care labour: precarity in the face of austerity. Journal of Industrial Relations 58, 473-490.

Deusdad BA, Pace C and Anttonen A (2016) Facing the challenges in the development of long-term care for older people in Europe in the context of an economic crisis. Journal of Social Service Research 42, 144-150.

Ervik R and Linden TS (2017) Samhandling mellom kommunen og frivillig sektor i eldreomsorgen. Rapport 2017:8 [Coordination Between the Municipality and the Volunteer Sector in Older Adult Care. Report 2017:8]. Oslo: Senter for forskning på sivilsamfunn og frivillig sektor. Available at https://samfunnsforskning.brage.unit.no/samfunnsforskning-xmlui/bitstream/handle/11250/2475847/VR_2017_8_Rapport_ V3.pdf? sequence $=2 \&$ isAllowed $=\mathrm{y}$.

Eurostat (2016) Participation in Formal Voluntary Activities in 2015, 16 Years or Over, EU-Statistics on Income and Living Conditions (EU-SILC). Available at https://ec.europa.eu/eurostat/web/income-and-living-conditions/data/database.

Finstad JA (2018) Nesten Hvert Fjerde Frivillige Årsverk er for Idretten [Almost Every Fourth Voluntary Full-time Equivalent is in Sports]. Oslo: Statistisk sentralbyrå. Available at https://www.ssb.no/nasjonalregnskap-og-konjunkturer/artikler-og-publikasjoner/nesten-hvert-fjerde-frivillige-arsverk-er-foridretten. 
Førland O (2015) Hva er frivillig innsats og frivillig omsorg? [What are volunteer efforts and volunteer care?]. In Jensen LH (ed.), Frivillighet $i$ omsorgssektoren. Tønsberg, Norway: Forlaget Aldring og helse, pp. 21-33.

Gautun H and Grødem AS (2015) Prioritising care services: do the oldest users lose out? International Journal of Social Welfare 24, 73-80.

Gori C (2019) Changing long-term care provision at the local level in times of austerity - a qualitative study. Ageing \& Society 39, 2059-2084.

Grootegoed E, Van Barneveld E and Duyvendak JW (2015) What is customary about customary care? How Dutch welfare policy defines what citizens have to consider 'normal' care at home. Critical Social Policy 35, 110-131.

Harrington C, Choiniere J, Goldman M, Jacosen FF, Lloyd L, McGregor M, Stamatopolos V and Szebehely M (2012) Nursing home staffing standards and staffing levels in six countries. Journal of Nursing Scholarship 44, 88-98.

Hulcko W, Brotman S and Ferrer I (2017) Counter-storytelling anti-oppressive social work with older adults. In Baines D (ed.), Doing Anti-oppressive Practice: Social Justice Social Work. Halifax, Canada: Fernwood Publishing, pp. 193-211.

Jacobsen F (2015) Understanding public elderly care policy in Norway: a narrative analysis of governmental White papers. Journal of Aging Studies 34, 199-205.

Jenhaug LM (2018) Myndighetenes forventninger til pårørende som samprodusenter i omsorgstjenester [The authorities' expectations of family carers as co-producers of care service]. Tidsskrift for Velferdsforskning 21, 39-58.

Kröger T and Leinonen A (2012) Transformation by stealth: the retargeting of home care services in Finland. Health and Social Care in the Community 20, 319-327.

Loga L (2018) Sivilsamfunnets roller i velferdsstatens omstilling [The roles of civil society in reforming the welfare state]. Norsk Sosiologisk Tidsskrift 2, 58-73.

Lorentzen H and Skinner MS (2018) Sektorisering av frivillig innsats og avgrensning av omsorgsbegrepet [Sectorialization of volunteer efforts and demarcation of the concept of care]. Tidsskrift for Omsorgsforskning 4, 117-119.

Lorentzen H and Tingvold L (2018) Frivillig innsats: Hindre i omsorgssektoren [Volunteer efforts: barriers in the care sector]. Tidsskrift for Omsorgsforskning 4, 120-131.

Ministry of Church and Culture - Church Affairs (2007) Frivillighet for alle. Meld. St. 39 (2006-2007) [Voluntarism for All. Report to the Storting 39 (2006-2007)] (White paper). Oslo: Ministry of Church and Culture-Church Affairs. Available at https://www.regjeringen.no/no/dokumenter/Stmeld-nr-392007-/id477331/.

Ministry of Culture (2018) Frivilligheita - sterk, sjølvstendig, mangfaldig - Den statlege frivilligheitspolitikken. Meld. St. 10 (2018-2019) [Voluntarism-Strong, Independent, Diverse-The Governmental Voluntary Policy. Report to the Storting 10 (2018-2019)] (White paper). Oslo: Ministry of Culture. Available at https://www.regjeringen.no/no/dokumenter/meld.-st.-10-20182019/id2621384/.

Ministry of Health and Care Services (2015a) Omsorg 2020 - Regjeringens Plan for Omsorgsfeltet 20152020 [Care Plan 2020. The Norwegian Government's Plan for the Care Services Field for 2015-2020]. Oslo: Ministry of Health and Care Services. Available at https://www.regjeringen.no/en/dokumenter/ care-plan-20202/id2410456/.

Ministry of Health and Care Services (2015b) Demensplan 2020. Et Mer Demensvennlig Samfunn [Dementia Plan 2020. A More Dementia Friendly Society]. Oslo: Ministry of Health and Care Services. Available at https://www.regjeringen.no/no/dokumenter/demensplan-2020/id2465117/.

Ministry of Health and Care Services (2018) Leve hele livet - En kvalitetsreform for eldre. Meld. St. 15 (2017-2018) [A Full Life-All Your Life - A Quality Reform for Older Persons. Report to the Storting 15 (2017-2018)] (White paper). Oslo: Ministry of Health and Care Services. English short version available at https://www.regjeringen.no/contentassets/196f99e63aa14f849c4e4b9b9906a3f8/en-gb/ pdfs/stm201720180015000engpdfs.pdf.

Ministry of Health and Care Services (2019) Folkehelsemeldinga - Gode liv i eit trygt samfunn. Meld. St. 19 (2018-2019) [Public Health Report - Good Lives in a Safe Society. Report to the Storting 19 (2018-2019) (White paper). Oslo: Ministry of Health and Care Services. Available at https://www.regjeringen.no/no/ dokumenter/meld.-st.-19-20182019/id2639770/. 
Norman L and Uba K (2015) Austerity Measures Across Europe, Technical Report. Available at http://www. livewhat.unige.ch/wp-content/uploads/2013/12/Austerity-Measures-Across-Europe.pdf.

Otnes B (2012) Utviklingslinjer i pleie- og omsorgstjenestene [Development lines in the care services]. In Daatland SO and Veenstra M (eds), Bærekraftig Omsorg. Familien, Velferdsstaten og Aldringen av Befolkningen (NOVA rapport 2/12). Oslo: NOVA, pp. 57-78. Available at https://oda.oslomet.no/odaxmlui/bitstream/handle/20.500.12199/5054/5390_1.pdf?sequence=1\&isAllowed=y.

Pavolini E and Ranci C (2008) Restructuring the welfare state: reforms in long-term care in Western European countries. Journal of European Social Policy 18, 246-259.

Putnam RD (2000) Bowling Alone: The Collapse and Revival of American Community. New York, NY: Simon \& Schuster.

Ranci C and Pavolini E (2015) Not all that glitters is gold: long-term care reforms in the last two decades in Europe. Journal of European Social Policy 25, 270-285.

Saraceno C (2010) Social inequalities in facing old-age dependency: a bi-generational perspective. Journal of European Social Policy 20, 32-44.

Skinner MS, Lorentzen H, Tingvold L, Sortland O, Andfossen NB and Jegermalm M (2020) Volunteers and informal caregivers' contributions and collaboration with formal caregivers in Norwegian long-term care. Journal of Aging \& Social Policy. Available online doi:10.1080/08959420.2020.1745988.

Spasova S, Baeten R, Coster S, Ghailani D, Peña-Casas R and Vanhercke B (2018) Challenges in Long-term Care in Europe. A Study of National Policies. Brussels: European Commission. Available at https://ec.europa.eu/social/main.jsp?langId=en\&catId=89\&newsId=9185.

Statistics Norway (2020a) Sjukeheimar, Heimetenester og Andre Omsorgstenester [Nursing Homes, Home Care Services, and Other Care Services]. Available at https://www.ssb.no/helse/helsetjenester/statistikk/ sjukeheimar-heimetenester-og-andre-omsorgstenester.

Statistics Norway (2020b) Nordmenn Legger ned Frivillig Innsats Verdt 78 Milliarder [Norwegians Contribute with Voluntary Efforts Worth 78 Billions]. Available at https://www.ssb.no/nasjonalregnskap-og-konjunkturer/artikler-og-publikasjoner/nordmenn-legger-ned-frivillig-innsats-verdt-78-milliarder.

Stuckler D, Reeves A, Loopstra R, Karanikolos M and McKee M (2017) Austerity and health: the impact in the UK and Europe. European Journal of Public Health 27, 18-21.

Szebehely M and Meagher G (2018) Nordic eldercare - weak universalism becoming weaker? Journal of European Social Policy 28, 294-308.

Ulmanen P and Szebehely M (2015) From the state to the family or to the market? Consequences of reduced residential eldercare in Sweden. International Journal of Social Welfare 24, 81-92.

Van den Broek T, Dykstra PA and Van der Veen RJ (2019) Adult children stepping in? Long-term care reforms and trends in children's provision of household support to impaired parents in the Netherlands. Ageing \& Society 39, 112-137.

Wollebæk D and Selle P (2002) Det nye Organisasjonssamfunnet-Demokrati i Omforming [The New Orgnisation Society - Democracy in Conversion]. Bergen, Norway: Fagbokforlaget.

World Health Organization (2015) World Report on Ageing and Health. Geneva: World Health Organization. Available at https://apps.who.int/iris/bitstream/handle/10665/186463/9789240694811_ eng.pdf? sequence $=1$.

Zigante V (2018) Informal Care in Europe. Exploring Formalisation, Availability and Qualtiy. Brussels: European Commission.

Cite this article: Ågotnes G, Moholt J-M, Blix BH (2021). From volunteer work to informal care by stealth: a 'new voluntarism' in social democratic health and welfare services for older adults. Ageing \& Society 1-17. https://doi.org/10.1017/S0144686X21001598 